DOI: $10.31249 / \mathrm{rsm} / 2019.04 .04$

\title{
Д.А. Волкова
}

\section{МИГРАЦИОННЫЙ ВОПРОС \\ В ЗАКОНОААТЕАЬСТВЕ И ПРОГРАММАХ ПОАИТИЧЕСКИХ ПАРТИЙ ЧЕШСКОЙ РЕСПУБАИКИ}

Аннотация. Статья посвящена анализу законодательства Чешской Республики, регулирующему миграционную политику страны. Рассмотрены как принципь законодательства Европейского союза, так и законы Чешской Республики, контролирующие нахождение мигрантов на территории Чехии.

Проанализированы статистические данные, опубликованные на сайте Чешского статистического ведомства за 2017 г. Статистика отражает численность законно прожсивющих мигрантов в стране в целом, а также мигрантов из России и Украины, в частности. Отмечается увеличение числа рабочих мигрантов из Украины, дается характеристика наиболее распространенных способов, используемых для того, чтобы остаться на территории Чехии для длительного проживания.

Особое внимание уделяется анализу программ политических партий, представленных в парламенте Чешской Республики после выборов 2017 г. и отношений лидеров партий к миграчионному вопросу. Источниковую базу составляют материаль официальных программ политических партий, заявления и выступления их лидеров и официальных представителей в средствах массовой информации. Выделены общие направления «левых» партий, которые в своих программах поддерживают миграцию на территорию Чешской Республики, а также отмечают необходимость эффективной интеграции иностранцев в чешское общество. В программах и публичных выступлениях представителей «правых» партий прослеживается тенденция $\kappa$ жесткому ограничению миграционных потоков. Тем не менее в связи с увеличением притока мигрантов на территорию Чешской Республики ожидается повышение значимости миграционного вопроса в программах партий.

Рассматривается необходимость координировать национальную политику Чешской Республики с общеевропейским вектором в вопросах миграции после вступления Чехии в Европейский союз в 2004 г., а такюе максимально ограничить потоки нелегальной миграции.

Ключевые слова: миграчия; трудовая миграчия; международная миграция; миграционное законодательство; «безвиз»; политические партии; Чешская Республика; Европейский союз. 


\title{
РОССИЯ И МИР В ХХІ ВЕКЕ
}

\author{
Волкова Дарья Андреевна - аспирант, \\ Российский государственный гуманитарный университет \\ (РГГУ), Москва. E-mail: dvolkova44@gmail.com
}

\section{D.A. Volkova. The Migration Issue in the Legislation and Programs of Political Parties of the Czech Republic}

Abstract. Analyzing the migration legislation in the Czech Republic, the author addresses both the European laws in this sphere and the Czech legislation regulating the presence of migrants in the country, their legal status and possibilities of acquiring Czech citizenship. The analysis is based on the statistics published on the website of the Czech Statistical Office for 2017, which shows the number of legal migrants in the country and the countries of their origin. It's indicated that the foreigners living in the country have mostly Ukrainian citizenship, others having moved from Slovakia, Vietnam, Russia, Poland and Germany. The most visible trend in this sphere is a sharp increase in the number of labor migrants from Ukraine.

Special attention is given to the programs of political parties represented in the Czech parliament after the 2017 elections as well as the attitudes of their leaders to the migration issue. To this end, the article focuses on the official parties' documents, statements of their leaders and their media presentations. Outlined are the main policy directions of the "left parties» whose leaders advocate the migration to the Czech republic and promote the idea of effective integration of migrants into the host society. By contrast, the programs and official statements of the "right-wing» parties tend to tightly restrict the migratory flows. In any case, owing to the growing influx of migrants into the country, this issue will be given increasing prominence in the parties' programs. In addition, after the Czech Republic joined the European Union in 2004, it is to follow the EU legislation and practices in defining its migration policies.

Keywords: migration; labor migration; international migration; immigration law; political parties; Czech Republic; European Union; Ukraine.

Volkova Daria Andreevna - Post-graduate Student,

Russian State University (RGGU), Moscow.

E-mail: dvolkova44@gmail.com

С начала тысячелетия Чехия переживает беспрецедентный рост миграции. Интеграция Чешской Республики в Европейский союз в 2004 г., а также вхождение в Шенгенскую зону в 2007 г. значительно закрепили эту тенденцию.

Согласно данным Чешского статистического ведомства, в 2016 г. число законно проживающих в Чехии иностранцев составило 493441 человек, при этом мигрантов из Украины - 22\% (109 850 человек) [Foreigners 2017, p. 37]. Основная цель миграции - трудовая миграция. По количеству иностранцев, зарегистрированных в бюро по трудоустройству, среди стран, не входящих 
в Европейский союз, мигранты из Украины занимают первое место - $14 \%$ от общего числа, второе место - мигранты из России - $2 \%$ от общего числа [Foreigners 2017, p. 57].

Центр миграционных потоков из Украины - Прага, предлагающая более выгодные условия, чем другие регионы страны, будь то рынок жилья или рынок труда. В Прагу стекаются $43 \%$ украинских мигрантов и $60 \%$ российских; 16\% украинцев выбирают Центральный край Чехии, 10\% мигрантов из Украины - Южноморавский край, в то время как, например, $8 \%$ россиян выбирают Карловы Вары [Foreigners 2017, p. 39].

Однако официальная статистика не учитывает незаконную миграцию. Борьба с незаконной миграцией стала в настоящее время одним из приоритетных направлений миграционной политики Чешской Республики. Речь идет о сокращении притока нелегальных мигрантов и в то же время это защита от незаконного перемещения иностранцев в стране. Эксперты не имеют единой точки зрения на то, являются ли строгие меры относительно въезда иностранцев в страну эффективными. Но они едины в том, что реальные цифры незарегистрированных иностранцев в несколько раз выше, чем показывают официальные источники.

Известно, что самый распространенный способ, благодаря которому трудовые мигранты остаются на территории Чехии, - использование краткосрочной туристической визы для въезда в страну с последующим нелегальным пребыванием [Foreigners 2017, p. 33].

В настоящее время мигранты образуют особую социальную сеть, вновь и вновь порождающую цикл миграции. Как только человек переезжает в другое место, вероятность миграции для его родственников, друзей и знакомых неизбежно повышается. Таким образом, число мигрантов постоянно увеличивается. Более высокий социальный статус мигрантов, их потребительская и инвестиционная активность меняются в лучшую сторону, что вызывает стимул к миграции у населения в стране происхождения [Čermáková, Nekorjak 2009, c. 33].

Исследователи также подсчитали, что в 2065 г. на территории Чешской Республики будут проживать почти $30 \%$ мигрантов и их семей. В соответствии с существующим развитием речь идет в основном о людях из Вьетнама, Китая, а также из Украины и других постсоветских республик [Čermáková, Nekorjak 2009, с. 9].

Сегодня Европейский союз занимает особое место в международной миграционной системе. Каждый год страны - члены Европейского союза принимают мигрантов, приезжающих на различные сроки и с различными целями. В настоящее время в Европейском союзе сложилась особая миграционная система, которая отличается тесным взаимодействием стран - членов $\mathrm{EC}$, что дает возможность говорить о единой миграционной сети. Будучи 
особым межгосударственным образованием, Европейский союз имеет свои экономические, культурные, политические, географические особенности, влияющие на тенденции развития миграционного вопроса.

Миграционная политика стран - членов Европейского союза направлена на граждан стран - членов ЕС и граждан стран, желающих получить политическое убежище. Она охватывает три уровня, а именно:

- межгосударственный;

- национальный;

- наднациональный [Čermáková, Nekorjak 2009, с. 3].

Миграционные процессы, осуществляемые на территории Европейского союза, контролируются, в первую очередь, Шенгенским соглашением. Однако структура европейской миграционной системы постоянно усложняется, так как наряду с привлекательными странами «старой Европы» формируются новые центры иммиграции в Центральной и Восточной Европе. Чехия сегодня представляет собой один из таких новых центров.

За последние десять лет в Чехии произошли значительные изменения в сфере миграции, что вызвало необходимость выработки более основательного и последовательного подхода, который повлек за собой соответствующие изменения и развитие на законодательном и политическом уровнях. Законодательная, политическая и организационная поддержка легальной миграции и интеграции, а также систематической борьбы со всеми формами нелегальной миграции стала основой миграционной политики [Чешская Республика 2010, с. 8].

В марте 2000 г. в Министерстве внутренних дел Чешской Республики создан новый Департамент по делам иммиграции и защиты государственной границы. В июле того же года он слился с Департаментом по делам беженцев и интеграции иностранцев МВД. В результате был создан Департамент по делам убежища и миграционной политики. Новый департамент стал основным ответственным органом по вопросам убежища и миграции в Чехии.

В 1999 г. была разработана политика интеграции иностранцев. С тех пор и до 2004 г. Министерство внутренних дел отвечало за разработку этой политики и управление ее внедрением. В 2004-2008 гг. эту функцию взяло на себя Министерство труда и социальных дел. В связи с тем что важным аспектом интеграции является безопасность, Министерство внутренних дел вернуло себе функцию главного координатора в вопросах интеграции иностранцев в Чехии и осуществляет ее по сей день [Čermáková, Nekorjak 2009, с. 8].

В 2003 г. чешское правительство утвердило Принципы иммиграционной политики Правительства Чешской Республики в отношении иностранцев фундаментального документа и основы построения современной и целевой иммиграционной стратегии Чехии. Заложенные в этом документе принципы в целом выражают решимость правительства Чехии активно и ответственно 
решать иммиграционные проблемы, выполняя при этом взятые на себя обязательства по соответствующим международным конвенциям, соглашениям, рекомендациям международных организаций. Эти принципы закладывают основу для решения конкретных задач в области миграции и в сферах, непосредственно связанных с ней. С учетом существующих национальных приоритетов выработка принципов на оперативном уровне предусматривает следующие аспекты и соображения:

- последовательное развитие сферы управления миграцией в связи с обязательствами, которые обусловлены членством в ЕС;

- разработка национальной иммиграционной политики, направленной на создание координированного подхода всех государственных и административных органов и учреждений, а также на сотрудничество с другими субъектами в иммиграционной сфере (такими как общественные и прочие гражданские организации);

- активизация усилий по искоренению всех форм нелегальной миграции и других, связанных с ней незаконных видов деятельности, путем принятия мер, учитывающих как национальные приоритеты, так и аспекты международного сотрудничества;

- оказание поддержки легальной миграции в соответствии с государственными приоритетами и учетом интересов в долгосрочной перспективе;

- участие Чехии в глобальных и европейских мероприятиях по преодолению миграционных последствий гуманитарных кризисов и устранению их причин [Zákon č. 55/2003].

Последнее десятилетие было отмечено двумя ключевыми моментами в области миграции, которые оказали значительное влияние на национальное законодательство и практику в отношении миграции и убежища. Первым было вхождение Чехии в Европейский союз в 2004 г., а вторым - вхождение в Шенгенскую зону в конце 2007 г. Первым шагом на пути к воплощению заявленных принципов было принятие в 2004 г. Плана действий по борьбе с нелегальной миграцией, разработанного Министерством внутренних дел и основанного на принципе № 3 [Usnesení 2004].

Закон о проживании иностранцев. Рассматриваются правовое регулирование иммиграционных условий нахождения иностранных граждан на территории страны и основные категории граждан, имеющих право на проживание в Чешской Республике. Законодательством Европейского союза контролируются пограничные и иммиграционные вопросы. Таким образом, Закон о проживании иностранцев отражает законодательство Европейского союза и / или ссылается на него [Zákon č. 326/1999].

Закон об убежище. Международная защита в форме убежища и вспомогательной защиты и порядок их предоставления регулируются Законом об убежище. В Законе об убежище рассматриваются вопросы, касающиеся лиц, 
ходатайствующих о предоставлении им международной защиты в Чешской Республике [Zákon č. 325/1999].

Закон о временной защите иностранцев. Оговаривает условия въезда и пребывания иностранцев с целью предоставления им временной защиты, порядок предоставления временной защиты, правовой статус лица, которому предоставлена временная защита. Чехия предоставляет временную защиту иностранцам, которые массово покинули страну своего гражданства или страну последнего места проживания и не могут вернуться обратно. Закон начал применяться после оглашения временной защиты Советом Европейского союза [Zákon č. 221/2003].

Закон о полиции Чешской Республики. Регламентирует защиту государственных границ и различные процедуры (установление личности, задержание, выдворение), связанные с иностранцами. Документ также регулирует отношения между полицией и Министерством внутренних дел в сфере обмена информацией из банков данных.

С 1 января 2009 г. вступил в силу новый Закон о полиции. В отношении иностранцев самым важным изменением стала передача полномочий в сфере оформления разрешений на проживание. Управление разрешениями на проживание постепенно перейдет от полиции к гражданскому органу - Департаменту по делам убежища и миграционной политики Министерства внутренних дел [Zákon č. 273/2008].

Закон о защите государственных границ. Закон регулирует защиту государственных границ от нелегального пересечения и обеспечивает выполнение обязательств, взятых на себя в соответствии с Шенгенскими соглашениями. Кроме того, в нем определены полномочия полиции в сфере обеспечения безопасности границ. В Законе также описаны действия, являющиеся нарушением этого закона [Zákon č. 216/2002].

Трудовой кодекс и Закон о труде. Новый Трудовой кодекс вступил в силу 1 января 2007 г. и стал одним из важнейших законов, который регулирует трудоустройство иностранцев [Zákon č. 262/2006].

Закон о труде определяет условия трудоустройства в Чешской Республике. В отношении иностранцев в нем установлены принципы приема иностранцев на работу, а также порядок выдачи иностранным гражданам разрешений на трудоустройство и зеленых / синих карт. Кроме того, в нем зафиксирована обязанность работодателей информировать Центр занятости о найме иностранцев. На основании этого закона после вхождения Чехии в Европейский союз граждане ЕС не считаются иностранцами и пользуются тем же правовым статусом, что и граждане Чехии [Zákon с̌. 435/2004].

Центры занятости отвечают за ведение документации об иностранцах, работающих в стране, а также о членах их семей, включая граждан стран, не входящих в состав Европейского союза. В Законе о труде и Законе об ино- 
странцах оговариваются меры контроля в сфере занятости. Эти законы предоставляют полиции и другим органам право заходить на территорию и на объекты работодателя.

В соответствии с поправкой к Закону о труде с начала 2009 г. Министерство внутренних дел принимает решения о предоставлении физическим и юридическим лицам права на оформление трудоустройства граждан третьих стран.

Закон о предоставлении и потере гражданства Чешской Республики. Закон о гражданстве предусматривает возможность предоставлять гражданство иностранцам на определенных условиях, таких как пять лет постоянного проживания на территории Чешской Республики [Zákon с̌. 40/1993].

В настоящее время важно гибко организовывать визовый режим между третьими странами и Европейским союзом, так как коммуникация между гражданами этих стран с каждым годом заметно увеличивается. К примеру, уже в 2006 г. по соглашению между Российской Федерацией и Европейским союзом, а также Украиной и Европейским союзом процесс выдачи виз был упрощен (на основании письменного обращения принимающей стороны) ряду категорий лиц. И финальной точкой в отношении Украины стало соглашение между Украиной и Европейским союзом об упрощении визового режима, вступившего в силу в 17 июня 2017 г.

Таким образом, вступление Чехии в Европейский союз, а также вхождение в Шенгенскую зону в конце 2007 г. существенно повлияли на развитие миграционной ситуации в Чехии. Чехия превратилась из транзитной страны преимущественно в страну назначения и сегодня миграционное законодательство Чешской Республики основывается на принципах и основных направлениях законодательства Европейского союза.

Сегодня в Чехии проживает бо́льшее число мигрантов, чем в какой-либо другой посткоммунистической стране Центральной и Восточной Европы [Koudelka 2014].

Увеличение числа мигрантов создает необходимость изменения законодательства страны в области миграции, в формировании миграционной политики, способствующей как регуляции миграционных потоков, так и противодействию развития таких негативных явлений, как безработица, преступность, нелегальная миграция и др.

На сегодняшний день миграционный вопрос находит свое отражение в программах различных политических партий Чехии, а также в публичных заявлениях по этому вопросу представителей партий, в их выступлениях в парламенте или на телевидении, радио, в текстах, публикуемых на официальных сайтах партий.

Сегодня в парламенте Чехии присутствуют следующие партии:

- $\mathrm{AHO}(\mathrm{ANO})$ «Акция недовольных граждан» - 29,64\%; 
- Гражданская демократическая партия (ODS) - 11,32\%;

- Чешская партия пиратов (Piráti) - 10,79\%;

- З За свободу и прямую демократию (SPD) - 10,64\%;

- Коммунистическая партия Чехии и Моравии (KSČM) - 7,76\%;

- Чешская социал-демократическая партия (ČSSD) - 7,27\%;

- Христианско-демократический союз - Чехословацкая народная партия (KDU - ČSL) - 5,80\%;

- Традиция Ответственность Процветание 09 (ТОР 09) - 5,31\%;

- Старосты и независимые (STAN) - 5,18\%.

Рассмотрим миграционный вопрос, отраженный в программах политических партий и заявлениях официальных представителей и лидеров партий.

AHO (ANO). В публичных выступлениях представителей партии прослеживается негативное отношение к активным миграционным потокам на территорию Чешской Республики, которые связывают с различного рода международными рисками, в том числе терроризмом, организованной преступностью, распространением оружия массового поражения и др. [Brezovská 2018]. Лидер партии премьер-министр Чехии Андрей Бабиш крайне настороженно относится к нелегальной миграции, воспринимает ее «как угрозу европейской цивилизации» и активно выступает за укрепление границ Евросоюза [Премьер 2018]. Бабиш отмечает в своих заявлениях, что бесконечный прием иностранных беженцев в Европу не решит проблемы. Он выступает за создание глобального плана по борьбе с нелегальной миграцией [Европа 2018]. Партия предлагает ограничить волны «безудержной миграции» на территорию страны [Čaněk 2013].

Сегодня представители партии поддерживают общеевропейский вектор миграционной политики, выражающийся в ограничении потока мигрантов. Однако в этом процессе им видится неоднозначность: наличие как позитивных моментов, так и негативных явлений. Актуальными являются опасения представителей партии распространения международного терроризма, а также оружия массового уничтожения по причине миграции из регионов, пострадавших от военных действий, - Среднего и Ближнего Востока.

Гражданско-демократическая партия (ODS). Программа партии, подготовленная для выборов в 2002 г., содержит критику политики правительства и партии социал-демократов, оставляющих без внимания увеличение притока мигрантов, а также предложения по ужесточению миграционной политики [ODS 2002].

На парламентских выборах в 2006 г. лидеры партии подчеркивали необходимость предотвращения преступной деятельности мигрантов и их нелегального проникновения в страну, а также увеличения контроля над теми работодателями, которые используют труд нелегальных мигрантов. 
При рассмотрении проекта введения зеленых карт в 2008 г. представитель партии Иво Стрейчек подчеркивал преимущества мигрантов как в трудовой сфере, так и в социальной. По словам сенатора Ярослава Куберы, существует необходимость принятия иностранцами местных культурных традиций. Он также подчеркивает необходимость соблюдения иностранцами всех законов и требований общества [Jaroslav Kubera 2013].

Если в программах до 2010 г. партия поддерживала общую миграционную политику Европы, то на парламентских выборах в 2010 г. подчеркнула необходимость свободно регулировать передвижения иностранцев внутри Чехии. Лидеры партии видят в миграционных потоках угрозу для сохранения традиций страны [Řešení 2010].

Более мягкая позиция видна в программе «Видение 2020», в которой Гражданско-демократическая партия старается все-таки подстроить регулирование на национальном уровне к масштабам общей европейской политики в области миграции.

Сегодня политика Гражданско-демократической партии выражается в желании снизить миграционные потоки в Чешскую Республику. А работа с теми, кто уже оказался на территории страны, должна основываться на процессе интеграции мигранта в чешское общество. Лидеры партии предлагают ввести более суровые законы для иностранных граждан по сравнению с законодательством для граждан Чехии, особенно эти требования касаются мусульманского населения [ODS 2002].

Чешская партия пиратов (Piráti). В настоящее время сложно дать оценку отношению лидера партии Ивана Бартоша к миграционному вопросу, тем не менее лидер партии Иван Бартош в своих интервью заявляет о том, что людям, которые бегут из стран, где ведутся боевые действия, нужна помощь, в отличие от «экономических мигрантов», прибывающих в Чехию на заработки [Bohuslavová 2017].

За свободу и прямую демократию (SPD). Ультраправая антимигрантская партия во главе с лидером Томио Окамура, который сам является мигрантом и одновременно сторонником ограничения миграции, выступает за оказание противодействия наплыву иностранных граждан [Айзпурвит 2017]. Многочисленные лозунги и плакаты партии перед выборами 2017 г. были направлены против миграции, а сам Окамура призывает мигрантов покинуть пределы Чехии, а чешское правительство - ужесточить контроль над миграцией и отказу от выдачи иностранцам постоянного вида на жительство [Томио Окамура 2014].

Коммунистическая партия Чехии и Моравии (KSČM). В программах Коммунистической партии отсутствует четкая позиция по отношению к миграционному вопросу. В программе, представленной на рубеже тысячелетий, однако, сказано, что правительству Чехии следует защищать права 
иностранцев, а также преодолевать негативное отношение к присутствующим в Чехии меньшинствам [KSČM 1999].

Сегодня коммунисты считают, что следует более строго регулировать миграционные потоки с целью защиты собственного населения. В настоящий момент Компартия выступает за более эффективный контроль «черного рынка», потоков нелегальной трудовой миграции и ужесточение наказаний за нарушение законодательства Чешской Республики [Dolejš 2015]. Тем не менее лидер партии Филип Войтех отмечает, что Чехия для мигрантов зачастую является «перевалочным пунктом» и скорее следует помогать тем странам, из которых направлены миграционные потоки [Вашкова 2018].

Чешская социал-демократическая партия (ČSSD). Миграционная политика вошла в программу социал-демократов в начале этого тысячелетия. Первое наиболее важное упоминание появилось в программе, посвященной миграции «Открытость новым вызовам, верность традициям» в 2003 г. [Základní 2003]. Партия в программе указывает на риски в сфере безопасности, однако мигранты воспринимаются как положительный фактор в увеличении численности населения Чешской Республики. В следующих долгосрочных программах подчеркивается неизбежность миграционных потоков на территорию Чехии. Избирательную программу для выборов в депутаты в 2006 г. характеризует защита иностранцев от дискриминации. «Государство должно создать условия, чтобы иностранцы могли интегрироваться и стать экономически самостоятельными». Цели в области безопасности включают ограничение нелегальной миграции и нелегального трудоустройства иностранцев [Jistoty 2006].

В программе «Изменения и надежды. Лучшее будущее для простых граждан», подготовленной для выборов в 2010 г., подчеркивается приоритет славян - выходцев из стран Южной и Юго-Восточной Европы [Změny 2010]. В целом можно сказать, что программы социал-демократов воспринимают миграцию как естественное явление, приносящее государству преимущества, хотя и не без риска. По мнению социал-демократов, государство должно создавать условия, позволяющие более тесную интеграцию.

В выступлении на радио в 2008 г. бывший лидер партии и экс-глава правительства Владимир Шпидла высказал мнение о том, что миграционные потоки необходимы Чехии в условиях демографического старения населения. Однако он обратил внимание на то, что в Чехии существует управляемая и неуправляемая миграция, последняя создает все необходимые условия для появления в стране «черного рынка» [Šmídová, Holub 2008].

В 2008 г. Гражданско-демократической партией (ODS) было предложено введение зеленых карт. Представители социал-демократов высказали свое мнение - в случае оформления зеленой карты мигрант не обязан проходить 
медицинское обследование, следовательно, возникает угроза появления на территории Чехии новых заболеваний [Bartos 2008].

Главным аргументом против введения в Чехии зеленых карт является отсутствие порядка действий по истечении срока действия указанного документа.

Социал-демократы - партия, приоритетами которой являются свобода, равенство и солидарность. В настоящее время политика партии в области миграции носит продуманный и концептуальный характер. Лидер партии и нынешний премьер-министр Богуслав Соботка заявил, что «сегодня Чехия должна избежать ошибок западных государств, где существуют трудноразрешимые конфликты. Чехия находится в ситуации, когда не может принять тысячи мигрантов, однако наша страна должна оставаться открытой для людей, которые нуждаются в получении убежища в результате политического преследования или в результате нарушения основных прав человека» [ČR neny].

Социал-демократическая партия поддерживает общую европейскую миграционную политику и настаивает на организации ведомства, которое смогло бы объединить и координировать миграционную деятельность государства.

Христианско-демократический союз - Чехословацкая народная партия (KDU - ČSL). В программах партии, относящихся к концу 1990-х годов, миграционный вопрос еще не был выделен. Первым документом, отразившим аспекты миграции, была программа «Общая ответственность» 2001 г., целью которой была ограничительная политика нелегальной миграции, незаконного трудоустройства, а также эксплуатации дешевой рабочей силы. В документе предлагались варианты легального доступа на рынок труда [Přepis 2001].

Интерес партии к вопросам миграции вырос в период с 2002-2004 гг. В это время появляется документ «Христианско-демократическая политика 21 века», в котором выражается беспокойство членов партии массовой миграцией в страны Европы, а также негативными демографическими явлениями региона [Křest’ansko-demokratická 2010].

В 2004 г. политика партии приобретает общеевропейские черты, отмечается необходимость создания общих условий предоставления убежища на всей территории Европейского союза. Однако подчеркивается право каждого государства - члена Европейского союза на самостоятельное регулирование миграционных вопросов. Представитель партии Йиндржих Карас в своей публикации отмечает потребность страны в миграционных потоках как реакцию на тенденцию старения чешского общества. Карас также говорит о возможности использования легальных мигрантов в качестве активных налогоплательщиков [Karas 2003]. 
Сегодня миграционная политика партии направлена на открытость страны для мигрантов, которая рассматривается как помощь развивающимся странам, а лидер партии экс-премьер-министр Чехии Павел Белобрадек оправдывает предоставление беженцам убежища на территории Чешской Республики с точки зрения европейского права [Туречкова 2015]. Одновременно лидеры партии обеспокоены социальными проблемами, которые возникают в связи с больши́м притоком мигрантов. Партия ищет решение демографических проблем в использовании внутренних человеческих ресурсов страны и обращает внимание на сохранение национальной однородности [Koudelka 2014]. Документы партии подчеркивают необходимость легальных мигрантов интегрироваться в общество страны [Tisková 2004].

Традиция Ответственность Процветание 09 (ТОР 09). По словам лидера партии, бывшего министра финансов ЧР Мирослава Калоусека, наплыв мигрантов - важный общеевропейский вопрос, однако Европа уже смирилась с тем, что беженцы в ней останутся. Важно в этой ситуации обеспечить грамотную ассимиляцию мигрантов в европейское общество [Щелков 2015]. Представители партии также отмечают, что политика государства должна быть открыта для иностранцев. Необходимо развивать стремление к общению с ними, чтобы избежать риска возникновения негативных явлений [Chalánková 2012]. Так, Йитка Халанкова заявила, что без миграционных потоков Европе грозит вымирание.

В программе партии, подготовленной к выборам 2010 г., указывалось, что партия стремится создать условия для наилучшей интеграции иностранцев с условием, что мигранты будут соблюдать законы и уважать культурные ценности чешского общества. Отмечалось также желание подавить «ксенофобские и расистские настроения» в обществе [Blažek 2010].

Из вышеизложенного следует, что политика партии ТОР 09 положительно относится к существованию миграционных потоков в Чехию, а также выступает за эффективную интеграцию иностранцев в чешское общество.

Старосты и независимые (STAN). В настоящий момент сложно оценить важность миграционного вопроса для этой партии, так как в открытых источниках лидеры партии Ян Фарский и Петр Газдик не делали заявлений на этот счет.

Итак, сегодня не во всех программах политических партий миграционный вопрос освещен в полном объеме. Возможно, это связано с опасениями лидеров партии о последствиях поднятой темы или относительно небольшим количеством иностранцев в области преступности [Лимонова 2012, с. 15]. После вступления Чехии в Европейский союз страна должна координировать национальную политику с общеевропейским вектором в вопросах миграции. Однако Чехия начала адаптировать свою политику еще за несколько лет до событий 2004 г. 
В настоящее время миграционная политика стала приоритетным направлением далеко не во всех программах политических партий. Однако можно выделить общие направления «левых» партий, таких как Чешская социалдемократическая партия (ČSSD) и Коммунистическая партия Чехии и Моравии (KSČM), которые в своих программах поддерживают миграцию на территорию Чешской Республики, а также отмечают необходимость эффективной интеграции иностранцев в чешское общество. В программах и публичных выступлениях представителей «правых» партий, таких как SPD, прослеживается тенденция к жесткому ограничению миграционных потоков. Тем не менее в связи с увеличением притока мигрантов на территорию Чешской Республики ожидается повышение значимости миграционного вопроса в приоритетных программах партий.

Несомненно, контроль легальной миграции, интеграция мигрантов на территории Европейского союза и ограничение нелегальной миграции - основные направления миграционной политики европейских государств. К важным направлениям миграционной политики Европейского союза также относится упрощение правил въезда на территории государств - членов Европейского союза узкоспециализированных специалистов и ученых, на интеграцию всех проживающих в ЕС мигрантов, а также на создание единого правового поля по урегулированию вопросов миграции, интеграции и этнического многообразия.

\section{Библиография}

Айзпурвит К. Сюрпризы и разочарования парламентских выборов // Radio Praha. Русская служба. 2017. 21 окт. URL: https://www.radio.cz/ru/rubrika/radiogazeta/syurprizy-i-razocharovaniya-parlamentskix-vyborov (Дата обращения: 21.02.2019.)

Вашкова Л. Чехия вновь сказала «нет» принятию беженцев // Radio Praha. Русская служба. 2018. 16 июля. URL: https://www.radio.cz/ru/rubrika/radiogazeta/chexiya-vnov-skazala-net-prinyatiyu-bezhencev (Дата обращения: 14.02.2019.)

Европа должна иметь глобальный план остановки миграции, заявил Бабиш // РИА Новости. 2018. 28 авг. URL: https://ria.ru/20180828/1527383472.html (Дата обращения: 10.03.2019.)

Лимонова Н.А. Влияние глобализации и интеграции на реализацию личностью свободы передвижения // Миграционное право. 2012. № 4. С. 6-10.

Маршева В. Результаты парламентских выборов в Чехии: триумф Бабиша, провал социалдемократов // 420 on.cz. 2017. 22 окт. URL: https://420on.cz/news/politics/54953-rezultaty-parlamentskih-vyborov-v-chehii-triumf-babisha-proval-sotsial-demokratov (Дата обращения: 10.03.2019.)

Премьер Чехии назвал миграцию из мусульманских стран угрозой для европейской цивилизации // ТАCC. 2018. 2 сент. URL: https://tass.ru/mezhdunarodnaya-panorama/5515485 (Дата обращения: 10.03.2019.)

Томио Окамура: нет работы - нет пособий // Пражский экспресс. 2014. 30 марта. URL: https://www.prague-express.cz/society/182-main-news/42148-2014-03-27-09-16-55 (Дата обращения: 21.02.2019.)

Туречкова Э. Квоты - опасный прецедент // Radio Praha. Русская служба. 2015. 23 сент. URL: https://www.radio.cz/ru/rubrika/radiogazeta/kvoty-opasnyj-precedent (Дата обращения: 28.02. 2019.) 


\section{РОССИЯ И МИР В ХХІ ВЕКЕ}

Чешская Республика. Расширенный миграционный профиль. Построение миграционных партнерств (ПМП) // Пражский процесс. Прага. 2010. 65 c. URL: https://www.pragueprocess.eu/ fileadmin/PPP/Czech_Republic_-_Extended_Migration_Profile_RU.pdf (Дата обращения: 24.02.2019.)

Щелков К. Мирослав Калоусек: «У Чехии типичный социалистический бюджет!» // Radio Praha. Русская служба. 2015. 01 сент. URL: https://www.radio.cz/ru/rubrika/tema/miroslavkalousek-u-chexii-tipichnyj-socialisticheskij-byudzhet (Дата обращения: 28.02.2019.)

Bartoš A.B. Cizinci k nám zavlečou tuberkulózu a AIDS, strašil ve Sněmovně Rath // iDNES.cz. 2008. 22 srpna. URL: http://zpravy.idnes.cz/cizinci-k-nam-zavlecou-tuberkulozu-a-aidsstrasil-ve-snemovne-rath-1dr-/domaci.aspx?c=A080822_132241_domaci_adb (Дата обращения: 21.02.2019.)

Beránková P., Rahimi F., Dvořáková M., Svetlíková M., Chocholáčková K. Česká imigrační politika: stát se vyhledávanou cílovou zemí? Program o českých zájmech v Evropě pro talanované studenty // Evropské hodnoty. 2013. URL: http://www.evropskehodnoty.cz/wp-content/uploads/ 2013/03/Background-paper_Imigrace-1.pdf (Дата обращения: 24.02.2019.)

Blažek J. Dušan Drbohlav a kol.: Migrace a (i)migranti v Česku: Kdo jsme, odkud přicházíme, kam jdeme? Praha: Slon, 2010. 207 s.

Bohuslavová R. Předseda Pirátů Bartoš: Nejsme vítači migrantů a jít do vlády se nebojíme // Novinky.cz. 2017. 10 ř́rjna. URL: https://www.novinky.cz/domaci/451459-predseda-piratu-bartosnejsme-vitaci-migrantu-a-jit-do-vlady-se-nebojime.html (Дата обращения: 21.02.2019.)

Brezovská K. Babiš: ČR nepřijme žádného dalšího migranta, chce celoevropské řešení migrace // Radio Praha. 2018. 28 srpen. URL: https://www.radio.cz/cz/rubrika/zpravy/babis-cr-neprijmezadneho-dalsiho-migrantachce-celoevropske-reseni-migrace (Дата обращения: 28.02.2019.)

Czech Civil Democratic Party elects the EU // Czech Civil Democratic Party: Official Website. URL: http://www.ods.cz/docs/programy/program_2002.pdf (Дата обращения: 21.02.2019.)

Čaněk M. Od vstř́cné důslednosti $\mathrm{k}$ nepřizpůsobivým imigrantům? Analýza tématu mezinárodní migrace $\mathrm{v}$ programech politických stran před volbami do Poslanecké sněmovny // Migraceonline.cz. 2013. 24 ř́ijen. URL: http://www.migraceonline.cz/cz/e-knihovna/od-vstricneduslednosti-k-neprizpusobivym-imigrantum-analyza-tematu-mezinarodni-migrace-v-programechpolitickych-stran-pred (Дата обращения: 28.02.2019.)

Čermáková D., Nekorjak M. Ukrainian middleman system of labour organisation in the Czech Republic // Journal of Economic and Social Geography. 2009. N 100 (1). P. 9-43.

ČR není v situaci, kdy by mohla prijímat tisíce migrantů // Oficiální stránky senátora Zdenka Shkromakh. URL: http://www.skromach.cz/item/cr-neni-v-situaci-kdy-by-mohla-prijimat-tisicemigrantu (Дата обращения: 21.02.2019.)

Dolejš (KSČM): Nejednoduché odpovědi na migraci // Parlamentí listy.cz. 2015. 19 leden. URL: http://www.parlamentnilisty.cz/politika/politici-volicum/Dolejs-KSCM-Nejednoduche-odpovedina-migraci-354833 (Дата обращения: 14.02.2019.)

Foreigners in the Czech Republic // Český statistický úr̆ad. 2017. 204 s. URL: https://www. czso.cz/documents/10180/45709982/29002717.pdf/770a1c14-6ea7-4c47-831e-3936e3ca1ab3?version= 1.2 (Дата обращения: 24.02.2019.)

Chalánková, J. Sociální soudržnost začíná v rodinách. 2011 // TOP 09: Official Website. 2012. 9 янв. URL: http://www.top09.cz/regiony/olomoucky-kraj/medialni-vystupy/socialni-soudrznostzacina-v-rodinach-8503.html (Дата обращения: 14.02.2019.)

Jaroslav Kubera: Žadatelé o státní občanství na něj mají právo, ne nárok // Český rozhlas Radiožurnál. 2013. 16 květen. URL: http://www.rozhlas.cz/radiozurnal/dvacetminut/_zprava/jaroslavkubera-zadatele-o-statni-obcanstvi-na-nej-maji-pravo-ne-narok--1212583 (Дата обращения: 21.02. 2019.) 
Jistoty a prosperita. Volební program ČSSD pro volby do Poslanecké sněmovny Parlamentu ČR // Oficiální web České sociálně demokratické strany. URL: http:/www.cssd.cz/data/files/volebniprogram-2006.pdf (Дата обращения: 20.02.2019.)

Karas J. Imigranti důchody nespasí // Hospodářské noviny. 2003. N 10 (nestránkováno).

Koudelka J. Imigrace a politické strany v České republice (2010-2013) // Globalpolitics. 2014. 27 февр. URL: http://www.globalpolitics.cz/clanky/imigrace-a-politicke-strany-v-ceske-republice2010-2013 (Дата обращения: 28.02.2019.)

Křest'ansko-demokratická politika ve 21. Století - věc velmi aktuální // Oficiální web «Křest’anské demokratické unie - Československé strany lidové». 2010. 8 duben. URL: http://www.kdu.cz/aktualne/archiv/2010/krestansko-demokraticka-politika-ve-21-stoleti-vec (Дата обращения: 28.02.2019.)

KSČM na přelomu tisíciletí. 1999 // Oficiální web Komunistické strany České republiky a Moravy. URL: http://www.sds.cz/docs/prectete/e_kolekt/pr_ks_99.htm (Дата обращения: 21.02.2019.)

ODS chce zpř́snit imigrační politiku // BBC. 2002. 15 května. URL: http://www.bbc.co.uk/ czech/lupacr/213.shtml (Дата обращения: 21.02.2019.)

Přepis z vystoupení Miloslava Výborného v pořadu Press klub // Oficiální web «Křest’anské demokratické unie - Československé strany lidové». 2001. 16 květen. URL: http://www.kdu.cz/aktualne/archiv/2001/prepis-z-vystoupeni-miloslava-vyborneho-v-poradu-p (Дата обращения: 28.02.2019.)

Řešení, která pomáhají. 2010 // Oficiální web České občansko-demokratické strany. URL: http://www.ods.cz/docs/programy/volebni-program2010.pdf (Дата обращения: 21.02.2019.)

Společně pro lepší život. Volební program 2006 // Oficiální web České občansko-demokratické strany. URL: http://www.ods.cz/docs/programy/program_2006.pdf (Дата обращения: 21.02.2019.)

Šmídová J., Holub P. Rozhovor s Vladimírem Špidlou // Český rozhlas Radiožurnál. 2008. 27 listopadu. URL: http://m.rozhlas.cz/cro6/stop/_zprava/520106 (Дата обращения: 20.02.2019.)

Tisková zpráva // Oficiální web Křest’anské demokratické unie - Československé strany lidové. 2004. 8 pochod. URL: http://www.kdu.cz/aktualne/archiv/2004/tiskova-zprava-(7) (Дата обращения: 28.02.2019.)

Usnesení vlády České Republiky č. 108/2004 o Akčním plánu boje s nelegální migrací ze dne 4 února 2004 // Vláda ČR. URL: https://kormoran.vlada.cz/usneseni/usneseni_webtest.nsf/0/ ABF17A44EF9AEBD9C12571B6006E39E5 (Дата обращения: 02.02.2019.)

Volební program TOP 09 pro Prahu. 2010 // Oficiální web strany «TOP 09». URL: http://www.top09.cz/files/soubory/praha-5-praha-13_168.pdf (Дата обращения: 14.02.2019.)

Základní dlouhodobý program ČSSD «Otevřenost novým výzvám, věrnost tradici»// Oficiální web České sociálně demokratické strany. URL: http://www.cssd.cz/data/files/dlouhodoby_program_ cssd_2003.pdf (Дата обращения: 20.02.2019.)

Zákon č. 216/2002 Sb., o ochraně státních hranic České republiky a o změně některých zákonů (zákon o ochraně státních hranic) ze dne 02 května 2002 // Zákony pro lidi. URL: http://www. zakonyprolidi.cz/cs/2002-216 (Дата обращения: 03.03.2019.)

Zákon č. 221/2003 Sb., o dočasné ochraně cizinců ze dne 26 června 2003 // Zákony pro lidi. URL: http://www.zakonyprolidi.cz/cs/2003-221 (Дата обращения: 03.03.2019.)

Zákon č. 262/2006 Sb., zákoník práce ze dne 21 dubna 2006 // Zákony pro lidi. URL: http://www.zakonyprolidi.cz/cs/2006-262 (Дата обращения: 03.03.2019.)

Zákon č. 273/2008 Sb., o Policii České republiky ze dne 17 července 2008 // Zákony pro lidi. URL: http://www.zakonyprolidi.cz/cs/2008-273 (Дата обращения: 03.03.2019.)

Zákon č. 325/1999 Sb., o azylu ze dne 11 listopadu 1999 // Zákony pro lidi. URL: http://www. zakonyprolidi.cz/cs/1999-325 (Дата обращения: 03.03.2019.)

Zákon č. 326/1999 Sb., o pobytu cizinců na území České republiky ze dne 23 dubna 2014 // Zákony pro lidi. URL: http://www.zakonyprolidi.cz/cs/1999-326 (Дата обращения: 03.03.2019.) 


\section{РОССИЯ И МИР В ХХІ ВЕКЕ}

Zákon č. 40/1993 Sb., České národní rady o nabývání a pozbývání státního občanství České republiky ze dne 29 prosince 1992 // Zákony pro lidi. URL: http://www.zakonyprolidi.cz/cs/1993-40 (Дата обращения: 03.03.2019.)

Zákon č. 435/2004 Sb., o zaměstnanosti ze dne 13 května 2004 // Zákony pro lidi. URL: http://www.zakonyprolidi.cz/cs/2004-435 (Дата обращения: 03.03.2019.)

Zákon č. 55/2003 Vyhláška, kterou se mění vyhláška č. 478/2000 Sb., kterou se provádí zákon o silniční dopravě // Zákony pro lidi. URL: http://www.zakonyprolidi.cz/cs/2003-55 (Дата обращения: 03.03.2019.)

Změny a naděje. Lepší budoucnost pro obyčejné občany lidi 2010 // CSSD.cz: Oficiální web České sociálně demokratické strany. URL: http://www.cssd.cz/data/files/volebni_program_velky 2010.pdf (Дата обращения: 03.03.2019.)

\section{References}

Aizpurvit K. Surprises and disappointments of parliamentary elections. Radio Praha. Russian Service. 2017. 21 Oct. URL: https://www.radio.cz/ru/rubrika/radiogazeta/syurprizy-i-razocharovaniya-parlamentskix-vyborov (Date of access: 21.02.2019.) (In Russ.)

Bartoš A.B. Cizinci k nám zavlečou tuberkulózu a AIDS, strašil ve Sněmovně Rath. iDNES.cz. 2008. 22. srpna. URL: http://zpravy.idnes.cz/cizinci-k-nam-zavlecou-tuberkulozu-a-aids-strasil-vesnemovne-rath-1dr-/domaci.aspx?c=A080822_132241_domaci_adb (Date of access: 21.02.2019.)

Beránková P., Rahimi F., Dvořáková M., Svetlíková M., Chocholáčková K. Česká imigrační politika: stát se vyhledávanou cílovou zemí? Program o českých zájmech v Evropě pro talanované student. Evropské hodnoty. 2013. URL: http://www.evropskehodnoty.cz/wp-content/uploads/2013/ 03/Background-paper_Imigrace-1.pdf (Date of access: 24.02.2019.)

Blažek J. Dušan Drbohlav a kol.: Migrace a (i)migranti v Česku: Kdo jsme, odkud přicházíme, kam jdeme? Praha: Slon, 2010. 207 s.

Bohuslavová R. Předseda Pirátů Bartoš: Nejsme vítači migrantů a jít do vlády se nebojíme. Novinky.cz. 2017. 10 října. URL: https://www.novinky.cz/domaci/451459-predseda-piratu-bartosnejsme-vitaci-migrantu-a-jit-do-vlady-se-nebojime.html (Date of access: 21.02.2019.)

Brezovská K. Babiš: ČR nepřijme žádného dalšího migranta, chce celoevropské řešení migrace. Radio Praha. 2018. 28 srpen. URL: https://www.radio.cz/cz/rubrika/zpravy/babis-cr-neprijmezadneho-dalsiho-migrantachce-celoevropske-reseni-migrace (Date of access: 28.02.2019.)

Czech Civil Democratic Party elects the EU. Czech Civil Democratic Party: Official Website. URL: http://www.ods.cz/docs/programy/program_2002.pdf (Date of access: 21.02.2019.)

Čaněk M. Od vstř́ícné důslednosti $\mathrm{k}$ nepřizpůsobivým imigrantům? Analýza tématu mezinárodní migrace $\mathrm{v}$ programech politických stran před volbami do Poslanecké sněmovny. Migraceonline.cz. 2013. 24 ř́jen. URL: http://www.migraceonline.cz/cz/e-knihovna/od-vstricneduslednosti-k-neprizpusobivym-imigrantum-analyza-tematu-mezinarodni-migrace-v-programechpolitickych-stran-pred (Date of access: 28.02.2019.)

Čermáková D., Nekorjak M. Ukrainian middleman system of labour organisation in the Czech Republic. Journal of Economic and Social Geography. 2009. No. 100 (1). P. 9-43.

ČR není v situaci, kdy by mohla príijímat tisíce migrant. Oficiální stránky senátora Zdenka Shkromakh. URL: http://www.skromach.cz/item/cr-neni-v-situaci-kdy-by-mohla-prijimat-tisicemigrantu (Date of access: 21.02.2019.)

Czech Prime Minister called migration from Muslim countries a threat to European civilization. TASS. 2018. 2 Sept. URL: https://tass.ru/mezhdunarodnaya-panorama/5515485 (Date of access: 03.10.2019.) (In Russ.) 
Czech Republic. Extended migration profile. Building Migration Partnerships (PMP). Prague Process. Prague, 2010. 65 p. URL: https://www.pragueprocess.eu/fileadmin/PPP/Czech_Republic_-_ Extended_Migration_Profile_RU.pdf (Date of access: 02.24.2019.) (In Russ.)

Chalánková, J. Sociální soudržnost začíná v rodinách. 2011. TOP 09: Official Website. 2012. 9 янв. URL: http://www.top09.cz/regiony/olomoucky-kraj/medialni-vystupy/socialni-soudrznostzacina-v-rodinach-8503.html (Date of access: 14.02.2019.)

Dolejš (KSČM): Nejednoduché odpovědi na migraci // Parlamentí listy.cz. 2015. 19 leden. URL: http://www.parlamentnilisty.cz/politika/politici-volicum/Dolejs-KSCM-Nejednoduche-odpovedina-migraci-354833 (Date of access: 14.02.2019.)

Europe must have a global plan to stop migration, said Babish. RIA Novosti. 2018. 28 August. URL: https://ria.ru/20180828/1527383472.html (Date of access: 03.10.2019.) (In Russ.)

Foreigners in the Czech Republic // Český statistický úřad. 2017. 204 s. URL: https://www. czso.cz/documents/10180/45709982/29002717.pdf/770a1c14-6ea7-4c47-831e-3936e3ca1ab3?version= 1.2 (Date of access: 24.02.2019.)

Jaroslav Kubera: Žadatelé o státní občanství na něj mají právo, ne nárok // Český rozhlas Radiožurnál. 2013. 16 květen. URL: http://www.rozhlas.cz/radiozurnal/dvacetminut/_zprava/jaroslavkubera-zadatele-o-statni-obcanstvi-na-nej-maji-pravo-ne-narok--1212583 (Date of access: 21.02.2019.)

Jistoty a prosperita. Volební program ČSSD pro volby do Poslanecké sněmovny Parlamentu ČR // Oficiální web České sociálně demokratické strany. URL: http://www.cssd.cz/data/files/volebniprogram-2006.pdf (Date of access: 20.02.2019.)

Karas J. Imigranti důchody nespasí // Hospodářské noviny. 2003. No. 10 (nestránkováno).

Koudelka J. Imigrace a politické strany v České republice (2010-2013) // Globalpolitics. 2014. 27 февр. URL: http://www.globalpolitics.cz/clanky/imigrace-a-politicke-strany-v-ceske-republice2010-2013 (Date of access: 28.02.2019.)

Křest’ansko-demokratická politika ve 21. Století - věc velmi aktuální // Oficiální web «Křest’anské demokratické unie - Československé strany lidové». 2010. 8 duben. URL: http://www.kdu.cz/ aktualne/archiv/2010/krestansko-demokraticka-politika-ve-21-stoleti-vec (Date of access: 28.02.2019.)

KSČM na přelomu tisíciletí. 1999 // Oficiální web Komunistické strany České republiky a Moravy. URL: http://www.sds.cz/docs/prectete/e_kolekt/pr_ks_99.htm (Date of access: 21.02.2019.)

Limonova N.A. The influence of globalization and integration on the realization of freedom of movement by a person. Migration Law. 2012. No. 4. P. 6-10. (In Russ.)

Marsheva V. The results of parliamentary elections in the Czech Republic: the triumph of Babis, the failure of the Social Democrats. 420 on.cz. 2017. 22 Oct. URL: https://420on.cz/news/politics/ 54953-rezultaty-parlamentskih-vyborov-v-chehii-triumf-babisha-proval-sotsial-demokratov (Date of access: 10.03.2019.) (In Russ.)

ODS chce zpřísnit imigrační politiku. BBC. 2002. 15 května. URL: http://www.bbc.co.uk/ czech/lupacr/213.shtml (Date of access: 21.02.2019.)

Přepis z vystoupení Miloslava Výborného v pořadu Press klub // Oficiální web «Křest’anské demokratické unie - Československé strany lidové». 2001. 16 květen. URL: http://www.kdu.cz/aktualne/archiv/2001/prepis-z-vystoupeni-miloslava-vyborneho-v-poradu-p (Date of access: 28.02.2019.)

Řešení, která pomáhají. 2010. Oficiální web České občansko-demokratické strany. URL: http://www.ods.cz/docs/programy/volebni-program2010.pdf (Date of access: 21.02.2019.)

Schelkov K. Miroslav Kalousek: «The Czech Republic has a typical socialist budget!». Radio Praha. Russian Service. 2015. 01 Sept. URL: https://www.radio.cz/ru/rubrika/tema/miroslavkalousek-u-chexii-tipichnyj-socialisticheskij-byudzhet (Date of access: 02.28.2019.) (In Russ.)

Šmídová J., Holub P. Rozhovor s Vladimírem Špidlou. Český rozhlas Radiožurnál. 2008. 27 listopadu. URL: http://m.rozhlas.cz/cro6/stop/_zprava/520106 (Date of access: 20.02.2019.) 


\section{РОССИЯ И МИР В ХХІ ВЕКЕ}

Společně pro lepší život. Volební program 2006. Oficiální web České občansko-demokratické strany. URL: http://www.ods.cz/docs/programy/program_2006.pdf (Date of access: 21.02.2019.)

Tisková zpráva. Oficiální web Křest’anské demokratické unie - Československé strany lidové. 2004. 8 pochod. URL: http://www.kdu.cz/aktualne/archiv/2004/tiskova-zprava-(7) (Date of access: 28.02.2019.)

Tomio Okamura: no work - no benefits. Prague Express. 2014. 30 March URL: https://www.prague-express.cz/society/182-main-news/42148-2014-03-27-09-16-55 (Date of access: 02.21.2019.) (In Russ.)

Turechkova E. Quotas - a dangerous precedent. Radio Praha. Russian Service. 2015. 23 Sept. URL: https://www.radio.cz/ru/rubrika/radiogazeta/kvoty-opasnyj-precedent (Date of access: 02.28.2019.) (In Russ.)

Usnesení vlády České Republiky č. 108/2004 o Akčním plánu boje s nelegální migrací ze dne 4 února 2004. Vláda ČR. URL: https://kormoran.vlada.cz/usneseni/usneseni_webtest.nsf/0/ABF17A 44EF9AEBD9C12571B6006E39E5 (Date of access: 02.02.2019.)

Vashkova L. Czech Republic again said «no» to the acceptance of refugees. Radio Praha. Russian Service. 2018. 16 July. URL: https://www.radio.cz/ru/rubrika/radiogazeta/chexiya-vnovskazala-net-prinyatiyu-bezhencev (Date of access: 02.14.2019.) (In Russ.)

Volební program TOP 09 pro Prahu. 2010 // Oficiální web strany «TOP 09». URL: http://www.top09.cz/files/soubory/praha-5-praha-13_168.pdf (Date of access: 14.02.2019.)

Základní dlouhodobý program ČSSD «Otevřenost novým výzvám, věrnost tradici». Oficiální web České sociálně demokratické strany. URL: http://www.cssd.cz/data/files/dlouhodoby_program cssd_2003.pdf (Date of access: 20.02.2019.)

Zákon č. 216/2002 Sb., o ochraně státních hranic České republiky a o změně některých zákonů (zákon o ochraně státních hranic) ze dne 02 května 2002. Zákony pro lidi. URL: http://www. zakonyprolidi.cz/cs/2002-216 (Date of access: 03.03.2019.)

Zákon č. 221/2003 Sb., o dočasné ochraně cizinců ze dne 26 června 2003. Zákony pro lidi. URL: http://www.zakonyprolidi.cz/cs/2003-221(Date of access: 03.03.2019.)

Zákon č. 262/2006 Sb., zákoník práce ze dne 21 dubna 2006. Zákony pro lidi. URL: http://www.zakonyprolidi.cz/cs/2006-262 (Date of access: 03.03.2019.)

Zákon č. 273/2008 Sb., o Policii České republiky ze dne 17 července 2008. Zákony pro lidi. URL: http://www.zakonyprolidi.cz/cs/2008-273 (Date of access: 03.03.2019.)

Zákon č. 325/1999 Sb., o azylu ze dne 11 listopadu 1999. Zákony pro lidi. URL: http://www. zakonyprolidi.cz/cs/1999-325 (Date of access: 03.03.2019.)

Zákon č. 326/1999 Sb., o pobytu cizinců na území České republiky ze dne 23 dubna 2014. Zákony pro lidi. URL: http://www.zakonyprolidi.cz/cs/1999-326 (Date of access: 03.03.2019.)

Zákon č. 40/1993 Sb., České národní rady o nabývání a pozbývání státního občanství České republiky ze dne 29 prosince 1992. Zákony pro lidi. URL: http://www.zakonyprolidi.cz/cs/1993-40 (Date of access: 03.03.2019.)

Zákon č. 435/2004 Sb., o zaměstnanosti ze dne 13 května 2004. Zákony pro lidi. URL: http://www.zakonyprolidi.cz/cs/2004-435 (Date of access: 03.03.2019.)

Zákon č. 55/2003 Vyhláška, kterou se mění vyhláška č. 478/2000 Sb., kterou se provádí zákon o silniční dopravě. Zákony pro lidi. URL: http://www.zakonyprolidi.cz/cs/2003-55 (Date of access: 03.03.2019.)

Změny a naděje. Lepší budoucnost pro obyčejné občany lidi 2010. CSSD.cz: Oficiální web České sociálně demokratické strany. URL: http://www.cssd.cz/data/files/volebni_program_ velky2010.pdf (Date of access: 03.03.2019.) 